\title{
NOVÁKY Erzsébet
}

Ez évi 4. számunk tanulmányai a Z generáció gondolatvilágának és jövőhöz való viszonyának témakörét állítják középpontba. Bemutatjuk a $Z$ generáció helyét a hazai generációk körében, és a fiataljaink körében végzett empirikus vizsgálat eredményein keresztül e generáció tagjainak elképzeléseit, várakozásait az elkövetkező 10 évre előre tekintve. Választ keresünk arra, hogy mit tehetünk fiataljaink fizikai-lelki állapotának javítása érdekében, valamint arra, hogyan terjednek el az új infokommunikációs eszközök és közösségek a felsőoktatásban. Milyen jövőalternatívák várhatóak a technikai fejlődés oldaláról és milyen változások észlelhetők a hazai kulturális életben, a kulturáltsági színvonalban - ezek a témakörök is szerepelnek a Tanulmányok rovatban.

2010-ben publikálta a Gazdasági és Szociális Tanács a „Magyarország 2025” című - az azonos témakörü akadémiai kutatás alapján összeállított - tanulmánykötetet. Ebben a Magyar Tudományos Akadémia megbízásából 2007-ben megkezdett kutatás eredményeit tettük közzé: szakértői előrejelzésekre és nem szakértői véleményekre építve körvonalaztuk hazánk lehetséges társadalmi-gazdasági jövőalternatíváit (a kutatásvezető és az alkotó szerkesztő Nováky Erzsébet volt). E kutatás keretében empirikusan vizsgáltuk, hogy miként gondolkodnak a hazai végzős középiskolások és egyetemisták az elkövetkező évekről, különös tekintettel a 2025-ös év Magyarországáról.

2015-ben már csak 10 év választott el bennünket a 21. század első negyedének végétől, amikor úgy véltük, hogy érdemes e kutatás - új feltételek közötti - megismétlése. Az új tanulmánykötet összeállt. $A$ nyomdai átfutás miatt a hard copy kézbevételére még várnunk kell, ezért a kutatás keretében készült az on-line folyóirat profiljába vágó - tanulmányokból átadunk egy csokrot, élve a modern technika előnyeivel, és megelőzve a teljes tanulmánykötet megjelenését. Ezzel az olvasói kíváncsiságot kívánjuk kielégíteni és jó ügyet szolgálni: minél előbb eljuttatni a legújabb hazai jövőkutatási szakirodalom néhány termékét minél szélesebb olvasótáborhoz.

Besenyei Lajos, rector emeritus „A generációváltás forradalma” c. tanulmányában hangsúlyozza, hogy a Z generáció, az ún. digitális bennszülöttek, a világ első globális nemzedéke. Természes közeg számukra az internet és a legújabb digitális eszközök is. A tudást, az információt - az Y generáció tagjaihoz hasonlóan - elsősorban nem a szüleiktől vagy a tanáraiktól szerzik meg, hanem a kortársaiktól, hasznosítva az internet nyújtotta előnyt: a valós idejű információk minél hamarabb történő beépítését ismerethalmazukba. Az így gondolkodó fiatalok mindent rögtön akarnak tudni - és sokszor nemcsak egyfajta megközelítésben -, logikus tehát az internethez fordulásuk. Ez felborítja az oktatás régi rendjét, és tanáraink sem tudják egykönnyen kielégíteni a fiatalok igényeit. A generációk közötti feszültség nemcsak az oktatás területén, hanem a munka világában is megjelenik. A munkahelyek vezetői is gyakran értetlenül állnak a fiatalok munkaidőkezdetet és befejezést szem előtt nem tartó szemlélete és viselkedése elött. Mindez összefügg a fiatalok másfajta érték- és erkölcsi rendjével. Ahhoz, hogy harmóniát teremtsünk tanár/oktató - hallgató/diák - munkaadó között, alapvető változás szükséges.

Bernschütz Mária, Dörnyei Krisztina föiskolai docensek és Nováky Erzsébet professor emerita 2015-ben vállalkoztak az empirikus vizsgálat megismétlésére, és lehetőségük nyillt a 2007-es és a 2015-ös kutatások eredményeinek összehasonlítására. Az összehasonlítás megmutatta, hogy a jövőre vonatkozó 
elvárások megváltozhatnak, amit egyrészt a kor (korcsoportonként különböznek az elvárások), másrészt a környezeti és társadalmi változások is befolyásolnak, amelyek önmagukban is alakíthatják a fiatalok várakozásait, jövőre vonatkozó elvárásait. A válaszolók vélekedése - amint az kiviláglik a Mit várnak a fiatalok 2025-töl? címü tanulmányból - kritika a jelenröl, és reális kép a jövőröl. A fiatalok gondolkodásának középpontjában a külföldön tanulás és a külföldi munkavégzés áll. Hűek a barátaikhoz, a külföldi barátaikhoz is. Feltételezik, hogy jelenlegi barátaik 10 év múlva is azok maradnak. Nagy az igényük a pihenésre és a sportra. A rendszeres sportolás életformává válik, ami szintén jó terep a baráti kapcsolatok kiépítésére és ápolására. Vigyáznak az egészségükre és a függetlenségükre. Önkéntes munkát nem vállalnak, de jótékonykodnak (mindkét tevékenység végzésének valószínüsége csökkent a két felmérés között). 2015-ben kisebb arányban gondolják azt, mint 2007-ben, hogy 2025-re áttevődik a hangsúly az otthoni internetes tanulásra az iskolarendszerü tanulás helyett, és hogy több szakmát/diplomát szereznek. Hisznek - bár kevésbé, mint 8 évvel ezelött - az alternatív gyógymódokban.

Vass Zoltán, testmozgás szakértő a tanulmányában - Mit tehetünk és mit érhetünk el a fiatalok fizikailelki állapotának javitása érdekében? - viszonylag sötét képet fest a fiatalok egészségi állapotáról. Az életkor elöre haladtával egyre kevesebben sportolnak, és a fiataloknak alig egyötöde választja szabadidejében a sporttevékenységeket. A magyar ifjúság 70\%-a szabadidejét otthon tölti, s közel 60\%a fizikailag inaktív, ülő életmódot folytat. A mai fiatalok élete sokkal inkább a jelen- és élményorientált tevékenységek köré szerveződik, amivel nehezen tudnak versenyezni a következetes, rendszeres munkát és kitartást igénylő fizikai aktivitások és sporttevékenységek. A szerző rámutat arra, hogy tehetünk az egészséges társadalomért, de alapvetően másképpen kell élni, mint az eddig megszokott. Hangsúlyozza a minőségi testnevelés - amelynek célja olyan módszertani, tartalmi keret és hatásrendszer biztosítása, amelynek eredményeként a tanulókban kialakul az egészségtudatos, jövőorientált életvezetési kompetencia - fontosságát.

Az informatika beáramlását a felsőoktatásba és az infokommunikációs eszközök és közösségek növekvő szerepét tárgyalja Monda Eszter, $\mathrm{PhD}$ hallgató Az új infokommunikációs eszközök és közösségek várható elterjedése a felsőszintű oktatásban című tanulmányában. Megállapítja, hogy a távoktatás előnye, hogy idő és hely szempontjából rugalmas a tanulás, hátránya viszont a tanuló és tanár közötti interakciók hiánya. Ezt képes megadni az eLearning a web 2.0 és valódi képzésmenedzsment segítségével. $A z$ eLearning biztosítja ugyanis a különböző forrásokból és perspektívából szerzett tudáselemek integrációját, a kreativitást, támogatja a kritikai hozzáállást és az innovációt, s nő az együttműködés a tanár és a diákok között. Az eLearning előnyei nemcsak a hallgatók, hanem az oktató tanárok és a munkáltatók számára is kimutathatóak. A szerző az online tanulás felsőoktatásban való elterjedését a jövőkerék módszer alkalmazásával szemlélteti, amelynek segítségével feltárhatók a közvetlen és a közvetett hatások.

Tóth Attiláné, egyetemi docens tanulmánya - A technikai fejlődés hatása a társadalomra. Alternatívák a 2050-es évekre - hosszabb távra tekint előre. Felvázolja a katasztrófák világát, de az intelligens vagy okos társadalom képét is, amelyet az előző alternatívához képest más gyökérből indít. $E$ változások jellegzetes csoportját az informatika inspirálja. Az elmúlt 25 évben számos eredmény mutatható fel az informatika eredményeinek felhasználásával (átalakult a közlekedés irányítása, megváltozott a bármilyen irányú és tartalmú tájékozódás lehetősége, sok információhoz rövid idő alatt hozzá lehet férni, legyenek azok hírek, akár hazai, napi, vagy világgal kapcsolatosak). Az információkhoz való hozzájutás és az azokkal való bánásmód felerősítheti az amúgy is létező generációs ellentéteket és társadalmi szakadékot is előidézhet. Vajon van-e gazdasági és etikai ereje a társadalomnak ahhoz, hogy a mélyülő ellentétek 
feloldását elősegítse. A két alternatíva egymásra épülése pozitiv értelemben is elképzelhető: a digitalizáció fejlettségét felhasználhatnánk a katasztrófák kialakulásának megismerésére, előrejelzésére, ezzel eredményesebbé tehetnénk az elkerülést.

Azt, hogy milyen változások várhatóak kultúránk fő vonalaiban, színesen mutatja meg Koncz Gábor, egyetemi magántanár - A népesség kulturáltsági színvonalának változásai 2025-ig - című tanulmánya. Ráirányítja a figyelmet a migráció, a lomizás, a digitalizálás, az éghajlatváltozás és az elektromosságfüggőség kulturális következményei végig gondolásának szükségességére. Kiemeli a kulturális produktumok és produkciók kínálatának bővülésével és ezzel együtt az intézményi átalakulások, összeolvadások, bezárások hullámával összefüggő változásokat. A cigányoknak a magyarokhoz és más hazai nemzetiségekhez és etnikumokhoz viszonyítva eltérő tulajdonságokat mutató népesedési tendenciái - e népesség száma és Magyarországon belüli aránya - kényszerítő erővel veti fel az átfogó kulturális elemzések szükségességét. Azt tehát, hogy sajátos kultúrájukat felfogjuk és megismerjük, annak megfelelően segítsük az oktatási, képzési és foglalkoztatási új viszonyok kialakulását. Nagy távlatban, 2050-ig a migráció, a népvándorlás és a digitalizáció együttes vagy különkülön hatására mindenképpen kultúraváltás tanúi leszünk. A felkészüléshez és elviseléshez önmagunkat és egymást is „taní-/tani” kell.

E figyelemfelhívó tanulmányok önmagukban is érdekesek, de a tanulmánykötet többi tanulmányának körében még inkább azok lehetnek. Javasoljuk tehát: keressék a „Magyarország 2025-ben és kitekintés 2050-re" címü tanulmánykötetünket (Arisztotelész Kiadó, Budapest). 